\title{
HABITS OF THE HIBISCUS BEE, EMPHOR BOMBIFORMIS
}

\author{
By Charles Robertson, \\ Carlinville, Illinois.
}

The following paragraphs have been overlooked in the bibliography of this bee, and by authors who have made observations upon it. The passages have been shortened a little by leaving out some irrevelant words.

1. 205.- "Emphor bombiformis is by far the most abundant visitor (of Hibiscus lasiocarpus). Indeed, in two seasons' collecting of insects on flowers, I have failed to find this bee except on this plant. The female visits the flower for honey and pollen, her loose scopa being well adapted to hold the large grains. The male comes for honey and in search of the female. In sucking, this bee generally begins with 4 (the middle nectary on the right) and turns to the left, often missing 5 , but sometimes reversing, so as to empty all. Of 27 individuals, only 10 sucked 5 nectaries, 17 missing one or more. The 27 sucked 113 out of a possible 135, and missed 22."

2.- "Mr. Charles Robertson, of Carlinville, Ill., read a most interesting note upon the habits of the bee Emphor bombiformis. This bee, it was started, confines itself almost exclusively to Hibiscus, chiefly $H$. lasiocarpus. It was stated that in collecting these bees it is important to catch those flying around the plant without alighting, as these were generally the males, whilst those visiting the flowers for honey and pollen were the females. On August 5th, when walking along a dam with water on one side, he had noticed a female standing upon the water; she then flew to a bank, and he observed that she was carrying water to facilitate the excavation of hard ground, into which she was burrowing to build her nest. Sometimes one pellet of earth would be taken out after such an application of water, but at others three or even four. An interesting discussion followed which was participated in by Messrs. Osborn, Cook, Weed, Fletcher and others." Published in 1890 (2) and cited in 1918 (9), this was overlooked $\mathrm{y}$ two bibliographies (11 and 14). 
4, 31-2.- "As a typical case of an oligotropic bee, Emphor bombiformis may be mentioned. Both sexes occur in abundance on flowers of Hibiscus lasiocarpus, the female collecting the pollen, the males often spending the night in the flowers. The bees do not occur except when the Hibiscus is in bloom. Within several yards of the Hibiscus I have seen the female making nests in a dry bank, carrying water to soften the earth she was excavating. The bees coming out next year find the Hibiscus in bloom near by. The only visits to other flowers I have seen the bees make were to those in the neighborhood of the Hibiscus. Thus I have seen a single female sucking the nectar of Cephalanthus occidentalis, and another that of Vernonia fasciculata, as well as a single male sucking nectar' of Ipomoea pandurata. The outside visits in no way modify the essential relation of the bee to the Hibiscus."

9. - "The fact that Emphor bombiformis rests upon the water when drinking, mentioned under the above title by Frederick Knab (7) was observed in 1890 and was recorded in 2 . It is fairly certain that the bees were not drinking in the ordinary sense, but that they consisted exclusively of females which were getting water to soften the earth in which they were making excavations for their nests."

This passage is casually cited (11:588) under Knab, as if it related to "drinking" instead of carrying water, and in spite of the fact that Knab's observation was not new.

Phenology.-Hibiscus lasiocarpus blooms 59 days, July 20Sept. 16. Emphor bombiformis, its oligolege, flies 53 days, July 21-Sept. 11, the male 44 days, July 21-Sept. 2, the female also 44 days, July 30-Sept. 11 . The male is 9 days earlier than the female, which is about the average for males, 9.6 mentioned in 10. The female is 9 days later than the male, which is 13 less than the average for females given in 10. This is one of 5 longtongued bees in 10, 341. Grossbeck and Nichols give Aug. 22, 25 and Sept. 3.

Flower visits (7).- $\%$ c(2)-Malvaceae: Hibiscus lasiocarpus, H. militaris. 
o s(3)-Compositae: Vernonia fasciculata; ConvolvulaCEAE: Ipomœa pandurata; RUBiaceaE: Cephalanthus occidentalis.

$o^{7} \mathrm{~s}(5)$-Compositae: Cirsium lanceolatum; ConvolvulaCEAE: Ipomoea pandurata; MaLvaCEAE: Hibiscus lasiocarpus, H. militaris; Verbenaceae: Verbena stricta. Flowers also visited by the female are in italics. Of the general visits, 57.1 per cent fall under Mas, $\mathrm{Hb}$ and red (=red, purple etc.).

In my lists of visitors to local flowers I have distinguished the visits of the males and females and noted the pollen visits of the females. These are ignored and mixed with notes where the distinctions were not made. In 12, 149, it is stated that visits of nest-making bees should show the pollen visits of the female, the nectar visits of the female and the nectar visits of the male. This was carried out in 13. The female of Calliopsis andreniformis shows 33.3 per cent under Mas and 52.3 under red, while the male shows 27.5 under Mas and 48.2 under white. The pollen visits of the female show 48.7 under Mas and 47.3 under red, while the nectar visits show 30.4 under Mas and 56.5 under red. In 15, 82 it is shown that oligolectic bees exhibit remarkable differences in their pollen and nectar visits. At Hibiscus lasiocarpus, at Ipomoea pandurata and at Verbena stricta mean three different things. Probably most people would not regard the distinctions as important. Many people, however, think science and the applications of science are the same thing and that there is no conflict between science and 1000 conflicting religions. In references to my papers "Hibiscus" means H. lasiocarpus. The bee never occurs on $H$. trionum.

$E$. fuscojubatus (8) was based on comparison of three females from New Jersey with one of $E$. bombiformis from Georgia. Local specimens show that differences like those credited to these species are not constant are not correlated. Any repectable local collection is likely to discredit the validity of E. fuscojubatus. Twenty-two local females and 12 males vary as follows: mesonotum pale 22, 12; scutel ochraceous 18, 0 ; vertex rufofuscous 12 , 6; vertex ochraceous 3,3 ; front rufofuscous 6,3 ; front ochraceous 6,4 ; cubital cell 3 longer than second 7, 5. The hair of vertex varies from nearly black through ochraceous to quite 
pale. How can one tell that the characters of $E$. bombiformis are shown by one specimen or that Grossbeck's observations were on E.fuscojubatus?

Historically the relations of flowers and insects was a botanical subject as shown by the works of Sprengel, Darwin, Delpino, Mueller, Mac Leod and others. Most of the papers and abstracts are in botanical journals, a fact which indicates the place to look for the literature.

Dependence of $E$. bombiformis on pollen of $H$. lasiocarpus, and adaptation of scopa to large pollen grains was recorded in $\mathbf{1}$, 1888 (see also 2 and 4); habit of male of flying about flowers in search of the female, in 1, 1888, and 2, 1890; female carrying water to soften ground, in 2, 1890 (also in 4 and 9); phenological correlation with $H$. lasiocarpus and habit of nesting near it, in 4, 1899.

\section{Chronological Bibliography.}

1. 1888. Robertson, C. Zygomorphy and its causes. I-III. Bot. Gaz. 13: 146-51, 203-8, 224-30.

2; 1890 Habits of Emphor bombiformis. Proc. Ent. Club A. A. A. S. Can. . Ent. 22: 216-17. Abstract by James Fletcher?

3. 1893. Hibiscus lasiocarpus. Flowers and insects. XI. Bot. Gaz. 18: 270-1.

4. 1899. On the flower visits of oligotropic bees. Flowers and insects. XIX. Bot. Gaz. 28: 27-38.

5. 1905. Knuth, P. Handbuch der Blütenbiologie. 32: 417.

6. 1911. Grossbeck, J. A. A contribution toward the life history of Emphor bombiformis. Journ. New York Ent. Soc. 10: 238-43.

7. 1911. Knab, F. How Emphor drinks. Proc. Ent. Soc. Wash. 13: 170.

8. 1913. Nichols, M. L. Some observations on the nesting habits of the mining bee, Emphor fuscojubatus. Psyche 20: 107-12.

9. 1918. Robertson, C. How Emphor drinks. Can. Ent. 50: 320 . 
10. 1918. Proterandry and flight of bees. Ent. News 29: $340-2$.

11. 1920. Lutz, F. E. and Cockerell, T. D. A. Distribution and bibliography of N. A. Apidæ etc. Bull. Am. Mus. Nat. Hist. 42: 490-641.

12. 1922. Robertson, C. Data of anthecology. Flowers and insects. XXI. Bot. Gaz. 73: 149-52.

13. 1922. Synopsis of Panurgidæ. Psyche 29: 159-73.

14. 1922. Frison, T. H. Notes on life history etc. of Anthophora abrupta. Tr. Am. Ent. Soc. 48: 137-56.

15. 1924. Robertson, C. Color preference of bees. Flowers and insects. XXIII. Bot. Gaz. 78: 68-84. 

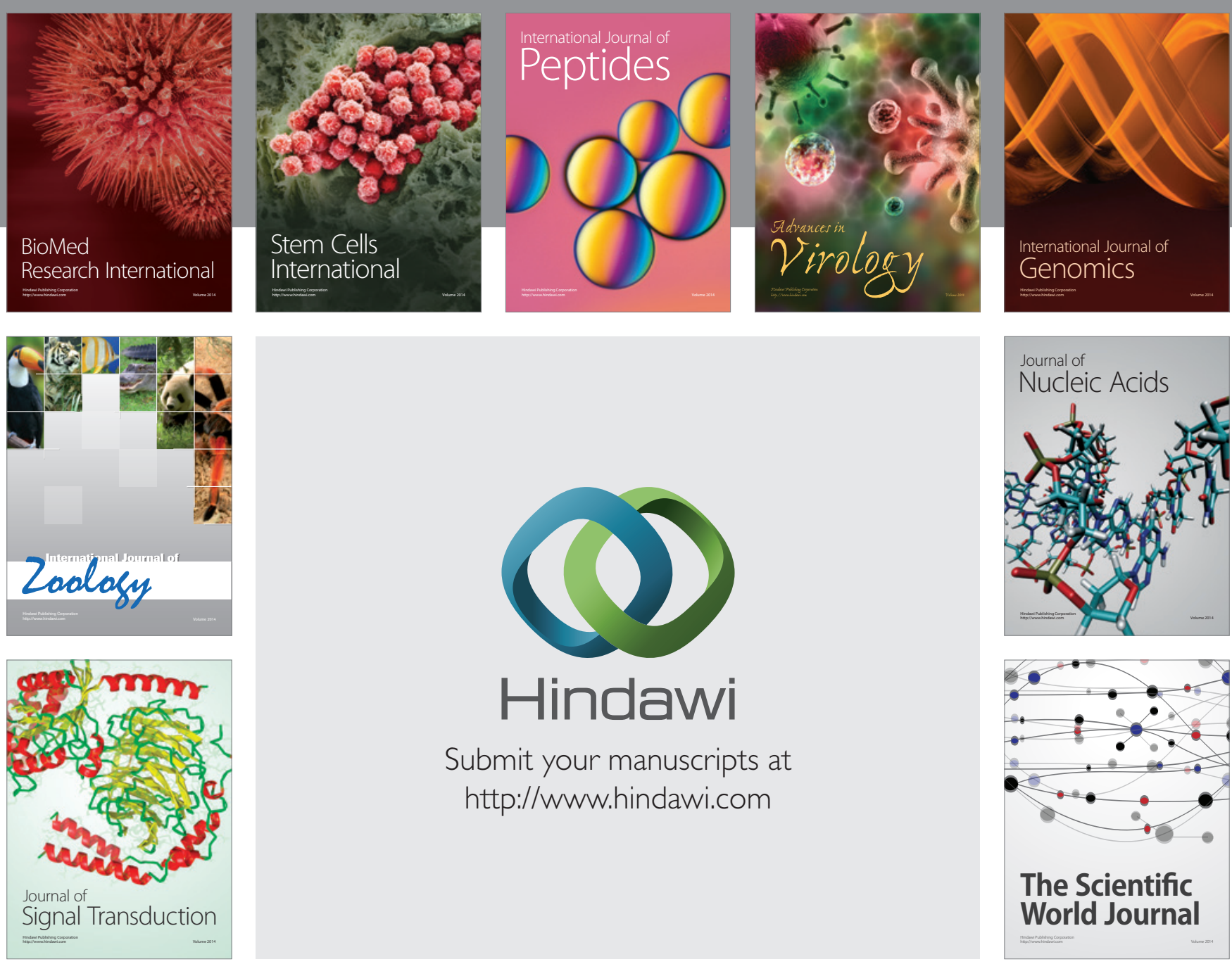

Submit your manuscripts at

http://www.hindawi.com
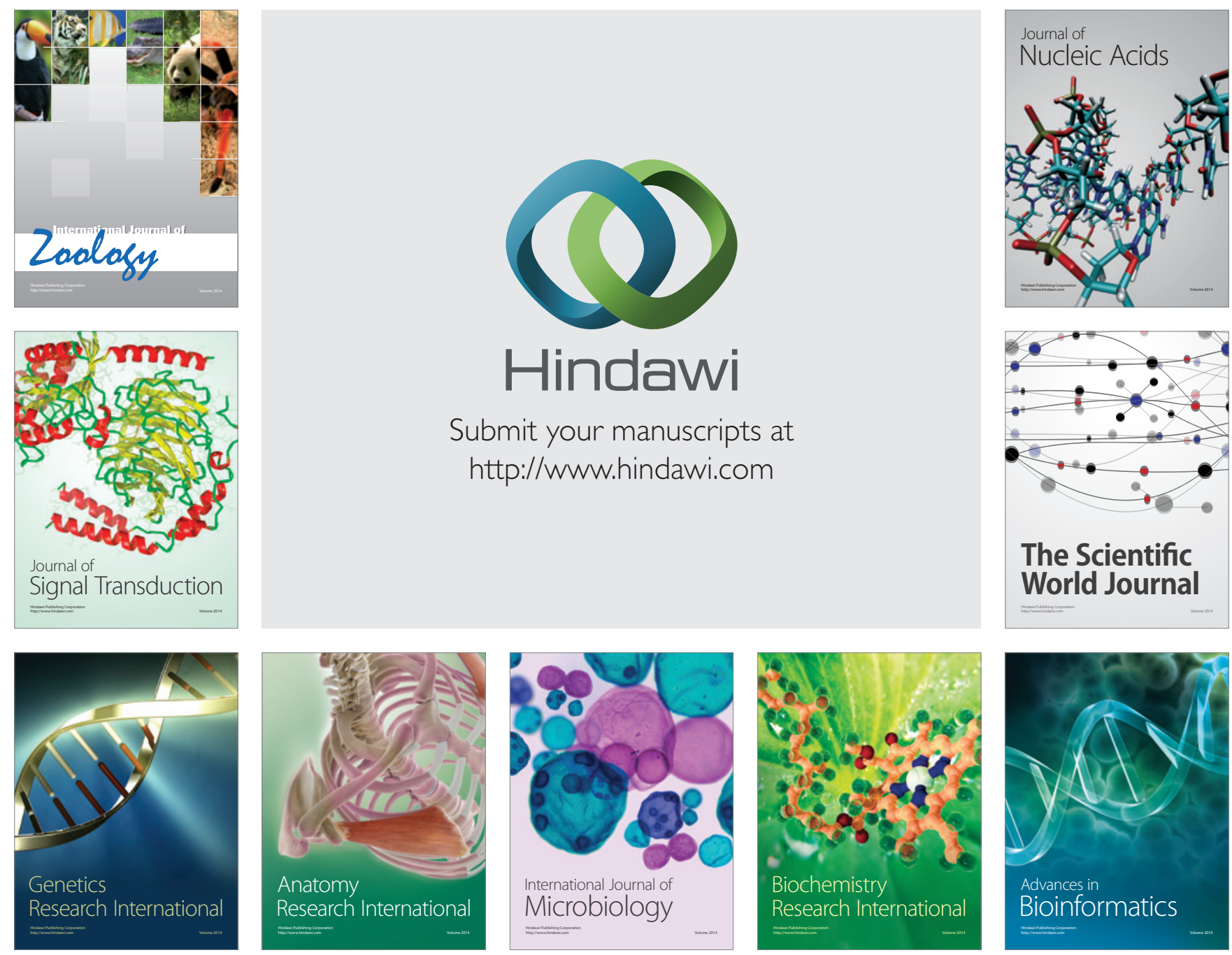

The Scientific World Journal
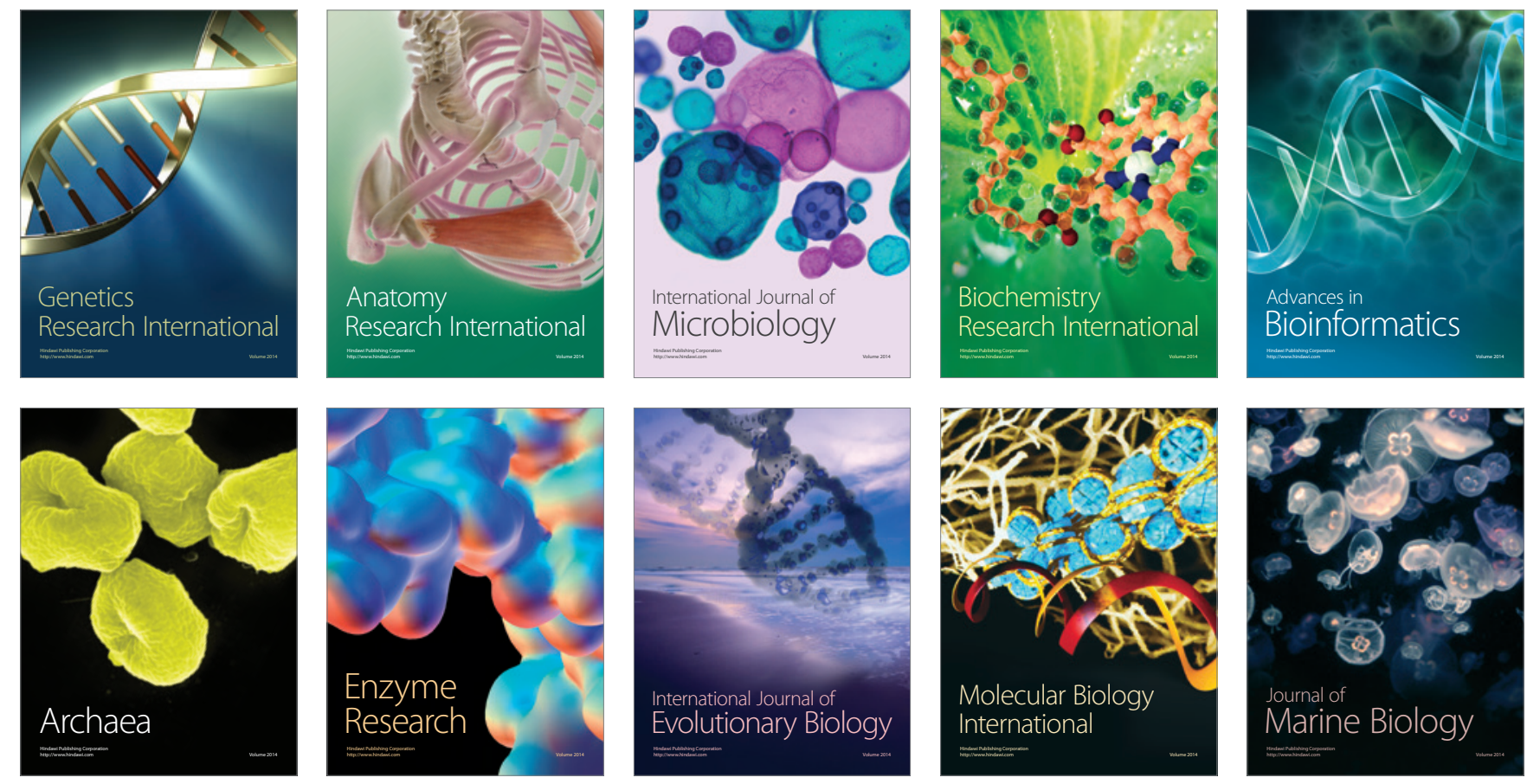